\title{
Instruments that evaluate the functioning in individuals affected with chikungunya and the International Classification of Functioning. A systematic review
}

\author{
Instrumentos que avaliam a funcionalidade em indivíduos acometidos com a chikungunya e a \\ Classificação Internacional de Funcionalidade. Revisão sistemática
}

Marina Carvalho Arruda Barreto¹, Bárbara Porfírio Nunes ${ }^{1}$, Shamyr Sulyvan de Castro²

DOI 10.5935/2595-0118.20190069

\section{ABSTRACT}

BACKGROUND AND OBJECTIVES: Currently, chikungunya has become an important health problem due to its painful symptomatology and the chronicity of this condition, which may compromise the functioning of individuals. Thus, using the International Classification of Functioning, Disability and Health, which focuses on functioning in the biopsychosocial context, this review sought to detect and assist in the selection of the most appropriate tool for measuring functioning in clinical practice and research. The objective of this study was to review the articles that have the functioning of individuals with chikungunya as an outcome, analyzing the instruments used for their evaluation and their relationship with the Classification model. CONTENTS: Systematic review of the literature in the Scielo, Pubmed, Scopus, LILACS, PEDro, and Cochrane databases. Observational or interventional studies were included. For the methodological evaluation of the articles, the Grading of Recommendations Assessment, Development and Evaluation system was used. From a total of 1579 studies found, after applying the inclusion/ exclusion criteria, and reading, five articles remained. The following frequencies were analyzed: health condition (3.86\%), function (3.86\%), body structure $(0.86 \%)$, activity $(67.82 \%)$, engagement $(8.15 \%)$, environmental factors $(8.15 \%)$ and personal factors (7.3\%). Only one of the five articles covered all the domains of the International Classification of Functioning.

CONCLUSION: There is a lack of tools that approach the functioning according to the model proposed by the International

\footnotetext{
Marina Carvalho Arruda Barreto - Dhttps://orcid.org/0000-0002-2505-6188;

Bárbara Porfírio Nunes - (Dhttps://orcid.org/0000-0001-8274-4203;

Shamyr Sulyvan de Castro - Dhttps://orcid.org/0000-0002-2661-7899.

1. Universidade Federal do Ceará, Mestranda do Programa de Pós-Graduação em Saúde Pública, Fortaleza, CE, Brasil.

2. Universidade Federal do Ceará, Fortaleza, CE, Brasil.

Submitted on February 14, 2019.

Accepted for publication on June 25, 2019.

Conflict of interests: none - Sponsoring sources: none.

Correspondence to:

Rua Dr. José Lourenço 816 apto 2101

60115-281 Fortaleza, CE, Brasil.

E-mail: shamyrsulyvan@gmail.com

(C) Sociedade Brasileira para o Estudo da Dor
}

Classification of Functioning, Disability and Health, for the population with chikungunya.

Keywords: Chikungunya fever, Disability and health, International Classification of Functioning.

\section{RESUMO}

JUSTIFICATIVA E OBJETIVOS: Atualmente a chikungunya vem se tornando um importante problema de saúde devido à sua sintomatologia dolorosa e à cronicidade dessa condição, que pode comprometer a funcionalidade dos indivíduos. Assim, através da utilização da Classificação Internacional de Funcionalidade, Incapacidade e Saúde, que tem como foco a funcionalidade no contexto biopsicossocial, esta revisão buscou detectar e auxiliar na escolha da ferramenta mais adequada para a medição da funcionalidade na prática clínica e nas pesquisas. O objetivo deste estudo foi revisar as publicaçóes que possuem a funcionalidade de indivíduos com chikungunya como desfecho, analisando os instrumentos utilizados para sua avaliação, verificando sua relação com o modelo da Classificação.

CONTEÚDO: Revisão sistemática da literatura, nas bases de dados Scielo, Pubmed, Scopus, LILACS, PEDro e Cochrane. Foram incluídos estudos observacionais ou de intervenção. Para a avaliação metodológica dos artigos foi utilizado o sistema Grading of Recommendations Assessment, Development and Evaluation. De um total máximo de 1579 estudos encontrados, após aplicação de critérios de inclusão/exclusão e leitura, restaram 5 artigos. Analisando a frequência dos domínios da Classificação Internacional de Funcionalidade, Incapacidade e Saúde encontrou-se: condição de saúde $(3,86 \%)$, função $(3,86 \%)$, estrutura do corpo $(0,86 \%)$, atividade $(67,82 \%)$, participação $(8,15 \%)$, fatores ambientais $(8,15 \%)$ e fatores pessoais $(7,3 \%)$. Apenas um dos cinco artigos contemplava todos os domínios.

CONCLUSÂO: Há carência de ferramentas que abordem a funcionalidade de acordo com o modelo proposto pela Classificação Internacional de Funcionalidade, Incapacidade e Saúde para a população com chikungunya.

Descritores: Classificação Internacional de Funcionalidade, Febre de chikungunya, Incapacidade e saúde.

\section{INTRODUCTION}

Chikungunya (CHIK) is a painful health condition caused by the Aedes mosquito bite infected with the chikungunya 
virus $(\mathrm{CHIKV})^{1}$. After the year 2000, there was a geographical expansion of the CHIKV ${ }^{1-4}$. The main symptoms are polyarthralgia, high fever in the early days, fatigue, edema, headache, among others ${ }^{5,6}$. In the acute condition, the population reports difficulties in getting around and performing their activities of daily and working life, adding to the losses in interpersonal relationships ${ }^{7,8}$. There are reports that the limitations remain in chronic stage 9 . Due to the painful and disabling symptoms, CHIK has become a major public health problem ${ }^{10}$.

In the context of a holistic analysis of the person, not having the disease as the main focus, the World Health Organization (WHO) published the International Classification of Functioning, Disability, and Health (ICF) ${ }^{11}$. This instrument promotes an approach to functioning and disability in the biopsychosocial context ${ }^{12}$. It proposes a new approach that increases environmental, personal, participation and activity factors in understanding the individual's situation ${ }^{13}$.

The ICF has seven domains: health condition, body functions, and structures, activity, participation, environmental and personal factors. There is a dynamic relationship between these domains, presenting itself as a network of correlations ${ }^{11,14}$. The concept of functioning brought by the WHO is a complex interaction between the health condition and contextual factors through a single and standardized language of health ${ }^{11}$.

This study aimed to study the instruments used to measure functioning in individuals affected with CHIK and to compare their consistency with the ICF model, seeking to detect whether these instruments are related to ICF, helping to make the most appropriate choice to measure functioning in clinical practice and research. Also, to check if the functioning is being approached according to the model proposed by the ICF.

\section{CONTENTS}

A systematic literature review study conducted from May to July 2018. Scielo, Pubmed, Scopus, LILACS, PEDro and Cochrane databases were used in English, Portuguese, and Spanish.

The following descriptors were used: impairment, functional performance, functionality, functional capacity, disability, chikungunya fever, chikungunya virus, in English, Portuguese, and Spanish. The combination was applied as follows: [(“Impairment" OR "Functional Performance" OR "Functionality" OR "Functional Capacity" OR "Disability")) AND ("Chikungunya Fever" OR "Chikungunya Virus")].

The inclusion criteria for the selection of articles were publications as of 2001 (year of publication of the ICF), and that assessed the functioning in individuals affected with CHIK. Review articles, theses, and dissertations were excluded.

The search and selection of studies were performed by two researchers independently, with a third researcher for cases of disagreement, which was not necessary. The researchers found 783 and 1579 articles, respectively. They used the same databases and descriptors, but one used the filters at the time of the search, and the other did not, creating the difference found in the number.

First, duplicate studies were excluded. Then, the screening by title and abstract was performed. The articles were read in full, with the selection of the eligible ones. All steps were performed individually. In the end, both found the same articles, five in total. Many studies assessed functional capacity or quality of life and not functioning, as was the expected outcome, so they excluded. Some articles addressed functioning in the microbiological aspects of mosquitoes. Figure 1 describes the selection process.

The selected studies were assessed according to methodological quality using the Grading of Recommendations Assessment, Development and Evaluation (GRADE). A system designed to achieve unification that is sensitive to grading the quality of evidence ${ }^{15,16}$. Publications can be graded into four levels of scientific evidence: high, moderate, low, very low. Among the articles found, four had low evidence and one moderate (Table 1).

The selected articles assessed the functioning through questionnaires, with no repetition of instruments. The second stage of the research consisted of coding these instruments by the ICF domains. This process consisted of the extraction of significant concepts considering the outcomes of the articles. The coding according to the ICF domains was performed by two independent coders taking into account the established and published rules $^{21}$. The process findings were compared, and discrepancies resolved with the supervision of the third researcher. The coding data are described in table 2 and figure 2.

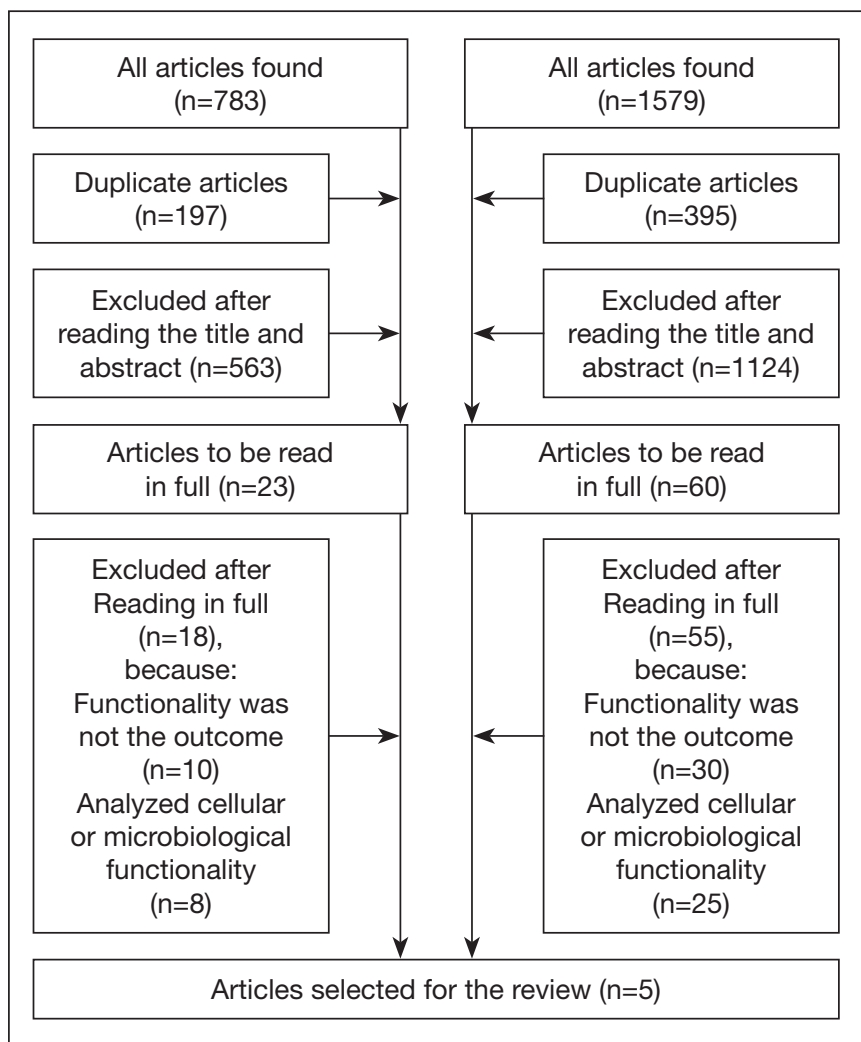

Figure 1. Article selection flow 
Table 1. General distribution of articles according to the number of participants, objectives, measurement instrument used and methodological quality score

\begin{tabular}{|c|c|c|c|c|}
\hline Authors & $\begin{array}{l}\text { No. of } \\
\text { participants }\end{array}$ & Objectives & $\begin{array}{l}\text { Functioning } \\
\text { instruments }\end{array}$ & $\begin{array}{l}\text { Quality } \\
\text { scores }\end{array}$ \\
\hline $\begin{array}{l}\text { Sepúlveda- } \\
\text { Delgado et al. }{ }^{17}\end{array}$ & 10 & $\begin{array}{l}\text { Assess the association between joint involvement, self-repor- } \\
\text { ted disability, and inflammatory biomarkers. }\end{array}$ & $\begin{array}{l}\text { WHO Disability Assess- } \\
\text { ment Schedule } 2.0\end{array}$ & Low \\
\hline Rahim et al. ${ }^{18}$ & 3869 & $\begin{array}{l}\text { Investigate the effects of chronic rheumatic and musculos- } \\
\text { keletal symptoms on the functional status of people affected } \\
\text { by the chikungunya epidemic in Calicut district, Kerala, sou- } \\
\text { thern India, in } 2009 \text {. }\end{array}$ & $\begin{array}{l}\text { Health Assessment Ques- } \\
\text { tionnaire (Modified - CRD } \\
\text { pune version). }\end{array}$ & Low \\
\hline Moro et al. ${ }^{3}$ & 250 & $\begin{array}{l}\text { Describe the clinical course and outcome of long-term chikun- } \\
\text { gunya infection. }\end{array}$ & $\begin{array}{l}\text { Recent-Onset Arthritis } \\
\text { Disability (ROAD) }\end{array}$ & Moderate \\
\hline $\begin{array}{l}\text { Bouquillard } \\
\text { et al. }{ }^{19}\end{array}$ & 307 & $\begin{array}{l}\text { Analyze the characteristics and progression of rheumatic ma- } \\
\text { nifestations in patients with post-chikungunya joint pain. }\end{array}$ & $\begin{array}{l}\text { Health Assessment Ques- } \\
\text { tionnaire }\end{array}$ & Low \\
\hline Heath et al. ${ }^{20}$ & 240 & $\begin{array}{l}\text { Investigate epidemiological, demographic, physical, and } \\
\text { behavioral risks. } \\
\text { Factors associated with the development of chikungunya vi- } \\
\text { rus-related chronic arthralgia in Granada }\end{array}$ & $\begin{array}{l}\text { Arthritis Impact } \\
\text { Measurement Scale }\end{array}$ & Low \\
\hline
\end{tabular}

Table 2. Frequency distribution of the domains of the International Classification of Functioning and Health contained in each instrument

\begin{tabular}{|c|c|c|}
\hline Article & Instruments & ICF domains n (\%) \\
\hline $\begin{array}{l}\text { Sepúlveda-Delgado } \\
\text { et al. }{ }^{17}\end{array}$ & WHO Disability Assessment Schedule 2.0 & $\begin{array}{l}\text { Health condition n:9 (11.54\%) } \\
\text { Function n:6 (7.7\%) } \\
\text { Body structure n:1 (1.28\%) } \\
\text { Activity n:39 (50\%) } \\
\text { Participation n:10 (12.88\%) } \\
\text { Personal factors n:8 (10.25\%) } \\
\text { Environmental factors n:5 (6.41\%) }\end{array}$ \\
\hline Rahim et al. ${ }^{18}$ & Health Assessment Questionnaire (Modified - CRD pune version). & $\begin{array}{l}\text { Activity n:46 (86.80\%) } \\
\text { Environmental factors n:7 (13.20\%) }\end{array}$ \\
\hline Moro et al. ${ }^{3}$ & Recent-Onset Arthritis Disability (ROAD) & $\begin{array}{l}\text { Function } \mathrm{n}: 3(13.04 \%) \\
\text { Body structure } \mathrm{n}: 1(4.35 \%) \\
\text { Activity } \mathrm{n}: 18(78.26 \%) \\
\text { Participation } \mathrm{n}: 1(4.35 \%)\end{array}$ \\
\hline Bouquillard et al. ${ }^{19}$ & Health Assessment Questionnaire & Activity n:31 (100\%) \\
\hline Heath et al..$^{20}$ & Arthritis Impact Measurement Scale & $\begin{array}{l}\text { Function n:2 (4\%) } \\
\text { Activity n:2 (48\%) } \\
\text { Participation n:8 (16\%) } \\
\text { Personal factors n:9 (18\%) } \\
\text { Environmental factors n:7 (14\%) }\end{array}$ \\
\hline
\end{tabular}

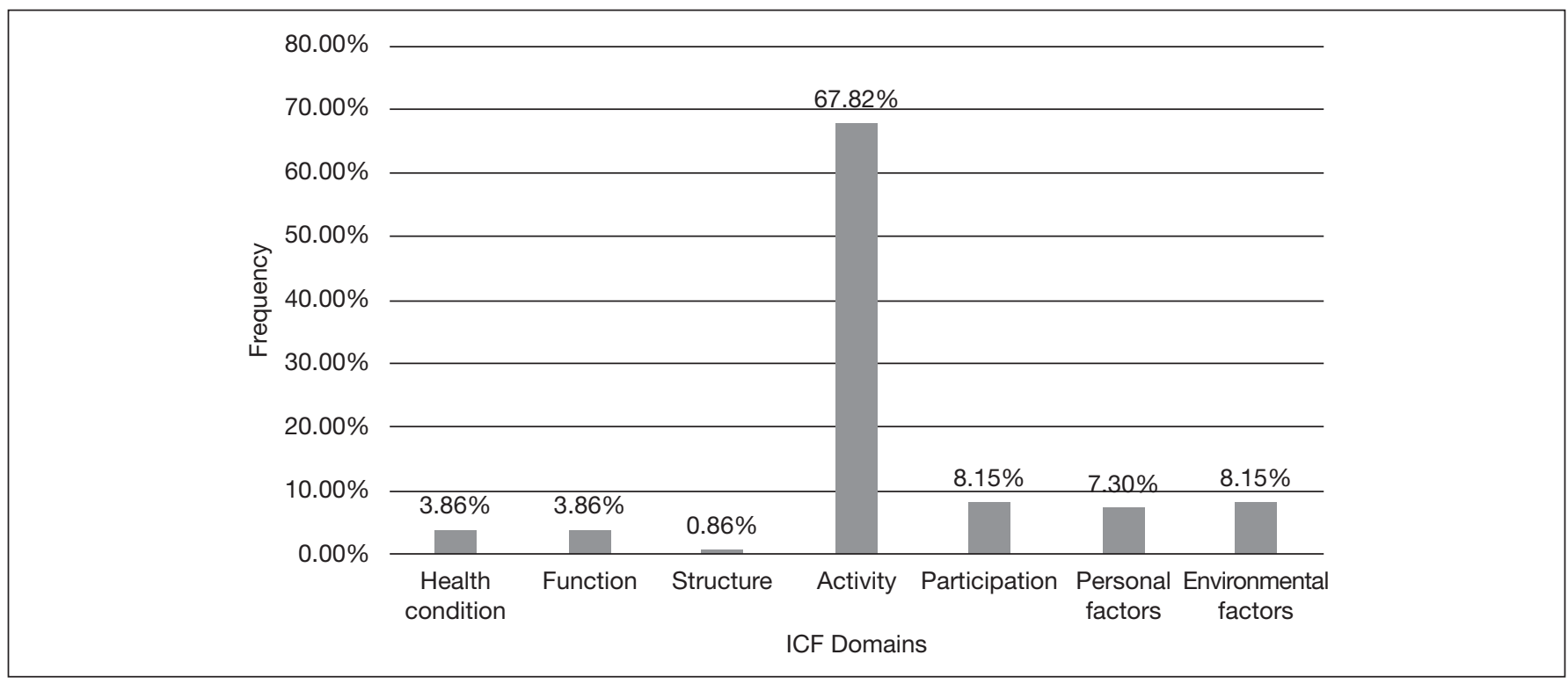

Figure 2. Domains of the International Classification of Functioning and Health that encodes the total frequency in the included instruments 
The frequency in which the domains appear in the collected instruments were: health condition $(3.86 \%)$, function $(3.86 \%)$, body structure $(0.86 \%)$, activity $(67.82 \%)$, participation $(8.15 \%)$, environmental factors $(7.3 \%)$ and personal factors $(8.15 \%)$. All domains were covered by at least one instrument, and only 1 covered all domains.

\section{DISCUSSION}

There was a range of articles that aimed to assess the functioning of people with CHIK. However, when analyzing the studies, the final sample consisted of five studies. This small number is due to the fact that most had the quality of life and/or functional capacity as their outcome, not functioning.

When analyzing the years of publication, there was an increase from 2016 to 2018, a fact that may be correlated with the increased geographic distribution of the virus ${ }^{1}$. The objective of the selected publications is directly related to the confirmation of the profile of the population affected with CHIK, having functioning as an outcome, which is with the purpose of this review.

Regarding the methodological assessment of the studies, most publications are of low quality, showing that the methodological elaboration needs to be more rigorous in execution, according to the GRADE system guidelines.

Among the selected articles, there was no repetition of instruments for the analysis of functioning, nor a consensus on which tool to use to assess the given outcome. In contrast, Gomes, Buranello and Castro ${ }^{22}$ found a physical test used in nine studies, by reviewing the instruments that assess functioning in the elderly.

It was observed that the population affected with CHIK has pain and difficulties in moving one or some joints, mainly: ankles, wrists, hands, and knees ${ }^{3,18,19}$, compromising the functioning of individuals to perform their activities and interpersonal relationships. When analyzing the correlation of the instruments with the ICF, a deficit in the structure domain was noted, where only one presented questions regarding this outcome, present in one question.

The WHODAS 2.0 was one of the questionnaires chosen to perform functioning analysis in individuals with $\mathrm{CHIK}^{17}$. When analyzing the correlation with the ICF, it was noticed that it addressed all domains, being the only one to present this characteristic, but $50 \%$ of its questions were activity-oriented, not homogeneous among the domains. WHO created it intending to analyze health and disability levels based on $\mathrm{ICF}^{23,24}$. Although not a validated instrument for CHIK, it is generic and cross-cultural, providing a standard measurement of functioning for any health condition ${ }^{24}$.

Rahim et al. ${ }^{18}$ used the Health Assessment Questionnaire (Modified - CRD Pune version), a version of the Stanford Health Assessment Questionnaire validated and modified for the Indian population ${ }^{25}$. This tool is widely used to assess rheumatic patients. The questionnaire focuses on the assessment of physical function and quality of life ${ }^{25}$, addressing only one aspect related to functioning. The relationship with the ICF reveals questions related to activities and environmental factors, showing a disagreement between what the instrument proposes to assess and what is really being considered in its structure, treating functioning in a limited way.

Another instrument used is the Recent-Onset Arthritis Disability in the validated version adapted for Italian patients with rheumatoid arthritis ${ }^{26}$. When checking the correspondence with the ICF, it was noticed that the instrument addresses four domains. In addition, $78.26 \%$ of the questionnaire refers to the activity, such as WHODAS 2.0, placing the other domains in a lower position and approaching the outcome narrowly. The same was found in the Arthritis Impact Measurement Scale (AIMS), when related to the ICF, its approach is mainly in the activity domain.

The study by Bouquillard et al. ${ }^{19}$ used the Health Assessment Questionnaire that assessed functional status through 20 questions $^{27}$. By correlating with the domains of the ICF, the tool addressed only the activity item, revealing the present biomedical perspective, not addressing important aspects of the ICF.

Only WHODAS 2.0 respects and addresses all the theoretical concepts presented by the ICF. It was produced by WHO for this purpose, as ICF does not assess but classifies it. The WHO recommends the use of this instrument to measure functioning $^{24}$. AIMS was the second tool that most covered the domains, excluding Health Structure and Condition.

There was disagreement among the instruments when addressing functioning with the predominance of activity. Thus, it seems that functioning is still understood in a reductionist and simplified way, placing activity in a higher importance perspective. However, the ICF seeks to treat its domains equally ${ }^{28}$.

Through the analysis of the research, some relevant data were found: lack of validation of the instruments for people with CHIKV (used for the general population or rheumatic conditions), and one of the studies had a very small sample. Also, almost all articles had low methodological quality, according to GRADE.

As a limitation of this study, there were a small number of articles that assessed the outcome in CHIK. It is attributed to the recent geographical expansion of the virus, resulting in a limited number of studies that seek to determine the consequences of this health condition. However, functioning is an indicator that has been gaining proportion in recent years, both in the field of science and health. Another limitation is regarding the languages of the publications since the search took place in only three languages.

The study has a prominent character since functioning is being seen as one important indicator to assess the population's health $^{29}$, and it is necessary to have an instrument that can address this outcome entirely. CHIK has become a major public health problem and data from this population need to be obtained for better clinical management.

\section{CONCLUSION}

The instruments used to measure functioning have shown to be related to the conceptual framework of the ICF, but most did 
not contemplate the structure in its entirety. WHODAS 2.0 stands out as the most reliable option for the assessment of this outcome, as it can cover all the concepts proposed by the classification, but it has limitations, lacking validated tools that show a complete approach to functioning and validated for the CHIK population. In addition, it is clear that the choice of instruments to measure functioning is not being made considering the relationship with the ICF.

\section{REFERENCES}

1. Burt FJ, Chen W, Miner JJ, Lenschow DJ, Merits A, Schnettler E, et al. Chikungunya virus: an update on the biology and pathogenesis of this emerging pathogen. Lancet Infect Dis. 2017;17(4):e107-17.

2. Leparc-Goffart I, Nougairede A, Cassadou S, Prat C, de Lamballerie X. Chikungunya in the Americas. Lancet. 2014;383(9916):514.

3. Moro ML, Grilli E, Corvetta A, Silvi G, Angelini R, Mascella F, et al. Long-term chikungunya infection clinical manifestations after an outbreak in Italy: a prognostic cohort study. J Infect. 2012;65(2):165-72.

4. Van Bortel W, Dorleans F, Rosine J, Blateau A, Rousseau D, Matheus S, et al. Chikungunya outbreak in the Caribbean region, December 2013 to March 2014, and the significance for Europe. Euro Surveill. 2014;19(13). pii:20759.

5. van Aalst E, Nelen CM, Goorhuis A, Stijnis C, Grobusch MP. Long-term sequelae of chikungunya virus disease: a systematic review. Travel Med Infect Dis. 2017;15:8-22.

6. Vijayan V, Sukumaran S. Chikungunya virus disease an emerging challenge for the rheumatologist. J Clin Rheumatol, 2016;22(4):203-11.

7. Couturier E, Guillemin F, Mura M, Léon L, Virion JM, Letort MJ, et al. Impaired quality of life after chikungunya virus infection: a 2-year follow-up study. Rheumatology. 2012;51(7):1315-22

8. Weaver SC, Lecuit M. Chikungunya virus and the global spread of a mosquito-borne disease. N Engl J Med. 2015;372(13):1231-9.

9. Marimoutou C, Ferraro J, Javelle E, Deparis X, Simon F. Chikungunya infection: self-reported rheumatic morbidity and impaired quality of life persist 6 years later. Clin Microbiol Infect. 2015;21(7):688-93.

10. Elsinga J, Grobusch MP, Tami A, Gerstenbluth I, Bailey A. Health-related impact on quality of life and coping strategies for chikungunya: a qualitative study in Curaçao. PLoS Negl Trop Dis. 2017;11(10):e0005987.

11. OMS OM da S. CIF: Classificação Internacional de Funcionalidade, Incapacidade e Saúde. Buchalla CM, editor. São Paulo: EDUSP; 2003.

12. Organizaçấo Mundial da Saúde. Como usar a CIF: Um Manual Prático para o uso da Classificação Internacional de Funcionalidade, Incapacidade e Saúde (CIF) Versão preliminar para discussấo. 2013;106.

13. Sampaio RF, Luz MT. [Human functioning and disability: exploring the scope of the World Health Organization's international classification]. Cad Saude Publica. 2009;25(3):475-83. Portuguese.

14. Farias N, Buchalla CM. A Classificaçăo Internacional de Funcionalidade, Incapacidade e Saúde da Organizaçấo Mundial da Saúde: Conceitos, Usos e Perspectivas. Rev Bras Epidemiol. 2005;8(2):187-93.

15. GRADE Working Group. GRADE working group. gradeworkinggroup.org/2016.

16. Brasil. Ministério da Saúde. Secretaria de Ciência T e IED de C e T. Diretrizes metodológica. Sistema GRADE - manual de graduação da qualidade da evidência e força de recomendação para tomada de decisão em saúde. 2013; 53:1689-99.

17. Sepúlveda-Delgado J, Vera-Lastra OL, Trujillo-Murillo K, Canseco-Ávila LM, Sánchez-González RA, Gómez-Cruz O, et al. Inflammatory biomarkers, disease activity index, and self-reported disability may be predictors of chronic arthritis after chikungunya infection: brief report. Clin Rheumatol. 2017;36(3):695-9.

18. Rahim AA, Thekkekara RJ, Bina T, Paul BJ. Disability with persistent pain following an epidemic of chikungunya in rural South India. J Rheumatol. 2016;43(2):440-4.

19. Bouquillard E, Fianu A, Bangil M, Charlette N, Ribéra A, Michault A, et al. Rheumatic manifestations associated with Chikungunya virus infection: a study of 307 patients with 32-month follow-up (RHUMATOCHIK study). Joint Bone Spine. 2018;85(2):207-10.

20. Heath CJ, Lowther J, Noël TP, Mark-George I, Boothroyd DB, Mitchell G, et al The identification of risk factors for chronic chikungunya arthralgia in Grenada, West Indies: a cross-sectional cohort study. Open Forum Infect Dis. 2018;5(1):ofx234.

21. Cieza A, Fayed N, Bickenbach J, Prodinger B. Refinements of the ICF Linking Rules to strengthen their potential for establishing comparability of health information. Disabil Rehabil. 2019;41(5):574-83.

22. Gomes CS, Buranello MC, Castro SS. Assessment instruments of functioning in Brazilian elderly and the ICF: a systematic review. Fisioter. Mov. 2017;30(3):625-37.

23. Üstün T, Kostanjsek N, Chatterji S, Rehm J. Measuring Health and Disability: Manual for WHO Disability Assessment Schedule WHODAS 2.0. World Health Organization. 2010

24. Castro SS, Leite CF, Osterbrock C, Santos MT, Adery R. Avaliação de Saúde e Deficiência: Manual do WHO Disability Assessment Schedule (WHODAS 2.0). Uberaba: Universidade Federal do Triângulo Mineiro - UFTM; 2015. 153p.

25. Chopra A, Saluja M. Validation and usefullness of Indian version (CRD Pune) health assessment questionnaire: Drug trials, community practice and COPCORD Bhigwan population study (1994-2012). Indian J Rheumatol. 2012;7(2):74-82.

26. Salaffi F, Stancati A, Neri R, Grassi W, Bombardieri S. Measuring functional disability in early rheumatoid arthritis: the validity, reliability and responsiveness of the Recent-Onset Arthritis Disability (ROAD) index. Clin Exp Rheumatol. 2005;23(5 Suppl 39):S31-42.

27. Bruce B, Fries JF. The Stanford Health Assessment Questionnaire: a review of its history, issues, progress, and documentation. J Rheumatol. 2003;30(1):167-78.

28. Fontes AP, Fernandes AA, Botelho MA. Funcionalidade e incapacidade: aspectos conceptuais, estruturais e de aplicaçáo da Classificação Internacional de Funcionalidade, Incapacidade e Saúde (CIF). Rev Port Saude Publica. 2010;28(2):171-8.

29. Stucki G, Bickenbach J. Functioning: the third health indicator in the health system and the key indicator for rehabilitation. Eur J Phys Rehabil Med. 2017;53(1):134-8. 